\title{
The Iron Age Cyclades And Crete: Different Approaches To CONNECTIVITY SPECUlatively RELATED To FoOd SECURITY
}

Doug Forsyth ${ }^{1}$

\section{ABSTRACT}

This paper offers a case study of some of the Cycladic Islands examining connectivity and insularity between 1000 - 500 BCE. In the Cyclades, evidence of interaction with areas outside of the archipelago and of intraisland connectivity is observable on many of the islands. It will be argued that environmental factors, predominantly low rainfall, may be at least part of the explanation for the adoption of a strategy of reaching out beyond an island's shores. Cycladic islanders plausibly sought to develop strong networks of affiliation with trading partners from other regions perhaps to serve as buffer zones to rely on during periods of poor food productivity. Compared to Cycladic material, the archaeological evidence of Cretan items found outside Crete is not as robust. This paper speculatively suggests that Cretans, living in a more fertile environment, did not feel the same need as Cycladic islanders to establish networks of affiliation for purposes of food security.

KEYWORDS

Cyclades, Crete, Connectivity, Rainfall, Food Security.

\footnotetext{
${ }^{1} \mathrm{PhD}$ in Ancient History, Associate researcher at University of St. Andrews, Scotland, United Kingdom. Email: dougforsyth55@gmail.com.
} 


\section{Introduction ${ }^{2}$}

The Cycladic Islands are in the centre of the Aegean Sea. East - west transit between mainland Greece and eastern areas such as Anatolia and the Levant necessitates passing through the island group. Similarly, north - south movement would likely pass through the Cyclades. The islands are not on the fringe of maritime communication routes, but rather are at the very centre of trans-Aegean movement and exchange (Constantakopoulou 2018, p.ix.). The large island of Crete is to the south of the Cyclades and forms the southern border of the Aegean Sea. East - west and some north - south maritime trade is observable in the Cretan record. This paper will provide case studies of the Cyclades and Crete examining aspects of insularity and connectivity during the Iron Age, 1000 - 500 BCE, the period following the end of the Bronze Age down to the arrival of larger political entities such as the Persians to the region. The examination focuses primarily on the Cycladic islands where low rainfall is an environmental constraint. A brief section discussing much better watered Crete is offered as a contrasting counter point to the Cycladic practices. Also discussed will be the impact of weather on maritime transport considering the ramifications for connectivity.

Archaeological evidence comprises the bulk of the examination. This evidence consists primarily of ceramics found in domestic, temple, and funerary deposits and from surveys. Types include drinking and domestic shapes as well as transport vessels. No shape or context is given greater importance than another, all are considered as evidence of some type of contact between peoples. ${ }^{3}$ Missing from the archaeological record are items that have not survived such as agricultural or pastoral products (independent of transport or storage vessels). These items may have been considerable. Ethnographic evidence from the $19^{\text {th }}$ century is introduced as well to highlight several environmental constraints of the region.

I have written elsewhere on the adoption by some Cycladic islanders of what I termed additive economic practices and contrasted this with economic practices in the Mirabello region of Crete (Forsyth 2020, PhD Thesis Economic and Social Development in the Iron Age Cyclades, 1000-480 BCE.). These Cycladic practices were economic

\footnotetext{
${ }^{2}$ The Author would like to thank the two external readers for their thoughtful and insightful comments that contributed much to this paper.

${ }^{3}$ Kotsonas 2011, p. 134-5 discussed the use of ceramic finds in Early Iron Age analysis. He argued (p. 1378) for the value of a close examination of the technical aspects of production techniques to establish provenance beyond motifs.
} 
activities that were additive to the base subsistence economy, broadly defined, and are observable on many, but not all, of the islands. I suggest the social decisions to engage in such practices were clearly economic, meant to produce additional goods and services that could be exchanged for material gain, and that they were strategic decisions, a product of human agency. It was a human plan to take advantage of the natural resources, geographic position, and new technologies for gain. It was an applied, practical strategy. In this paper I would like to suggest that a complimentary rationale to the creation of economic surpluses was achieving food security in an uncertain and fragile environment. This paper will propose that environmental factors, most notable the lack of rainfall, played a significant role in how Cycladic island connectivity developed. The comparatively plentiful finds of Cycladic materials stands in contrast to the less-plentiful evidence of connectivity from better-watered Crete, especially so given the relative size of the Cycladic islands to Crete. This suggests Cycladic islanders and Cretans developed different approaches with respect to insularity and networks and I propose that differing environmental conditions played an important role in their responses.

\section{Defining the Cyclades}

The Cyclades were a geographical association, not political. Individual inhabitants referred to themselves by the name of their island and not the archipelago. The Delian League assessments of the $5^{\text {th }}$ century BCE were made against individual islands, not the archipelago. ${ }^{4}$ Solon (fr. 2 G.-P. ${ }^{2}=1-3 \mathrm{~W}^{2}$ ) referred to the Folegandrians and Sikinoi, Herodotus $(8.1 .46,8.111 .2)$ referred to the Keans and the Andrians, Archilochos to the Mykonians (LOEB 259, Archilochos 124), and Demosthenes (13.34) to the Siphnians and Kythnians as did Pausanias (10.11.2). ${ }^{5}$ The Delian Assessment against the three independent poleis on Amorgos were grouped into the collective term Amorgoi. ${ }^{6}$

The Cycladic island group as defined today, consists of 32 islands (plus numerous islets and rocks) with an average size of $85 \mathrm{~km}^{2}$ per island. The group extends southeast from the tip of the Attic Peninsula. The nearest island to Attica is Keos, $12 \mathrm{~km}$ from Lavrion and the farthest island from the mainland is Thera, $180 \mathrm{~km} .{ }^{7}$ Geologically, the

\footnotetext{
${ }^{4}$ See Meritt, Wade-Gery, \& McGregor 1950, the Tribute tables listed all islands as a single category not divided into regional subsets such as Cycladic, Ionian, Aeolic, etc.

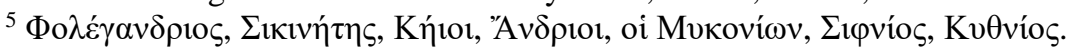

6 'A $\mu$ ópyır; Marangou 2002, p.28, n80.

${ }^{7}$ Dawson 2014, Table 6.4 lists 28 islands. This examination covers 32 islands in the central Aegean plus Crete.
} 
islands are volcanic, comprising the tops of mountains that rise above sea level (Sheedy 2006, p.16.). Most of the islands are formed around a central peak such as Paros, Siphnos, and Seriphos or are bisected by a long central ridge such as Keos, Amorgos, Andros, and Tenos. Sea levels have generally risen about two meters since antiquity, separating islands such as Paros and Antiparos that were once connected, perhaps as recently as the Archaic period. $^{8}$

The geology across the archipelago is not uniform. The western islands of Kea, Kythnos, Siphnos, Seriphos, Kimolos, and Melos are all predominantly micaceous schists and blue or grey limestone with extractable mineral resources of iron, copper, lead, silver, and kaolin (Cherry, et al. 1991, p.57). The central islands of Paros, Naxos and neighbouring smaller islands are primarily metamorphic schists and marble (Bruno, et al. 2010, pp.101-2.) Marble and emery were exploited but these islands lacked the mineral resources of the western islands. The northern islands of Andros and Tenos both are micaceous schists with iron and marble resources, neither of which seem to have been exploited in the Iron Age (Sheedy 2006; McGilchrist 2010(18), pp.104-5.) The southern island of Thera is unique in that it is largely covered in deep ash (Tzachili 2005, pp.2445.) The range of mineral resources in the Cyclades indicates a variety of possible exploitations could have been pursued by the inhabitants.

Artemidorus, quoted by Strabo (10.5.3), listed fifteen Cycladic Islands while Strabo recorded twelve and Pliny (Naturalis Historia 4.12.65-7) fourteen. The term Cyclades

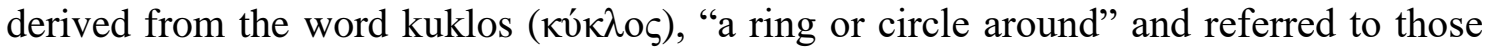
islands that circled around Delos, making the definition geographic. Yet the southern islands Amorgos $(80 \mathrm{~km})$ and Sikinos $(68 \mathrm{~km})$ are closer to Delos than is Keos $(82 \mathrm{~km})$. To the east, Ikaria $(64 \mathrm{~km})$ would seem to qualify if geographic proximity to Delos was the criterion. This suggests something else was involved. The Homeric Hymn to the Delian Apollo (3a.147-155) describes the 'long-haired Ionians' travelling to Delos to engage in feasting and competitions honouring Apollo. Thucydides (3.104) also mentioned that from ancient times there was a great assemblage of the Ionians and the neighbouring islanders at Delos for the celebration of a festival in honour of Apollo. The

\footnotetext{
${ }^{8}$ Kourayos, Sutton, \& Daifa 2018, p.115; Dawson 2014, pp.27-32, Figs 2.2a-c with diachronic maps of sea levels, Fig. 2.4; Draganits 2009.
} 
southern islands were considered Doric rather than Ionian and were associated traditionally with the Peloponnese. ${ }^{9}$

\section{Cycladic Evidence of Contact}

Iron Age evidence of contact both within the archipelago and further afield is considerable. Data from some of the islands is robust while from others the evidence is scant. A few examples are presented here.

The two central islands of Paros and Naxos are justifiably famous for their marble, exports of which can be found throughout the Mediterranean and beyond. ${ }^{10}$ On Paros, evidence of foreign contact is preserved in many locations. Finds from the Sanctuary to the Delian Apollo serve to illustrate this. Across the bay from Paroikia, is a 150-meter hill on which a series of cult structures occupy the summit. ${ }^{11}$ The earliest feature was a hypaethral altar of the $9^{\text {th }}$ and $8^{\text {th }}$ centuries. In the Late Archaic, a monumental marble temple was built (Ohnesorg 2017.). The earliest ceramics were Protocorinthian and Early Geometric. Protocorinthian vases including twenty aryballoi were well preserved (Rubensohn 1962, pp.8, 117-18.). Late Geometric Corinthian vases were found with oriental decorations in the form of running winged demons and animal motifs (Rubensohn 1962, p.125; Kourayos, Angliker, Daifa, \& Tully 2018, p.150.). Other finds included a necklace consisting of thirty pieces of which eighteen were faience scarabs (Rubensohn 1962, pp.73-6.). Rubensohn attributed four Egyptian faience figurines found in Late Geometric levels to Naucratis and remarked that Parian coins are of the earliest coinage found in Egypt, suggesting to him that Parian traders were in Egypt (Rubensohn 1962, p.169, Plate 35, Figs 1-4.). From the Sanctuary to Apollo on the neighbouring island of Despotiko, more finds from an array of distant locations were uncovered. Carefully arranged and preserved under floor paving stones in temple building A1, was a collection of small items from earlier cultic activities at the site (Kourayos \& Burns 2017, p.327, Fig. 1.). In this deposit, the largest group of imported ceramics are Corinthian, dated to

\footnotetext{
${ }^{9}$ Sheedy 2006, p.13, 15, n87; Craik 1980, pp.4-5; The traveller Pseudo-Skylax defined the Cyclades as we do today but divided them into two groups: "those islands off Lacedaemon (Melos, Kimolos, Oliaros (Antiparos), Sikinos, Thera, Anaphe, and Astypalia) and those off Attica (Keos, Helene (Makronisos), Kythnos, Seriphos, Paros, Naxos, Delos, Rhenia, Syros, Mykonos, Tenos, and Andros).

${ }^{10}$ See Schilardi \& Katsonopoulou (Eds.) 2010 Parian Lithos, Parian Quarries, Marble, and Workshops of Sculpture for a rich presentation of the marble trade.

${ }^{11}$ Rubensohn excavated the summit area in the 1920s, utilizing 20 workers over a period of just six days. Results were published post-war in 1962 just prior to his death.
} 
$7^{\text {th }}$ and first half of $6^{\text {th }}$ centuries (Kourayos \& Burns 2017, p.330, Fig. 7; Kourayos, et al. 2012, pp.124-7, Fig. 37.). These Corinthian imports (mainly aryballoi and alabastra) date to the same period as the increase in Corinthian material at Al Mina in northern Syria (Vacek 2017, pp.49, 54, Fig. 7.13; Boardman 2006, p.521.). Also found in the deposit are ivory fibulae and disks, as well as simple beads made of glass, stone, and faience, possibly of Syrian or Phoenician fabrication. The origin of these items has not been established beyond typology (Kourayos \& Burns 2017, pp.331-2, Figs 10, 11.).

Naxos is the only Cycladic island with secure evidence of continuous occupation from the Bronze Age. ${ }^{12}$ The settlement at Grotta appears to have been abandoned at the end of Late Helladic IIIC. On top of the abandoned settlement, seven Protogeometric graves and pottery were uncovered as well as three Protogeometric tombs in the adjacent Aplomata cemetery (Charalambidou 2018, pp.144-49; 2017, pp.375-6; Sfyroera 2018, pp.328-30; Thomatos 2006, pp.255; Mazarakis Ainian 1997, pp.188-9; Lambrinoudakis 1988, p.235.). Grave 12 from Aplomata contained a one-handled cup with three sets of compass-drawn concentric circles on the shoulder, evident of the new Protogeometric style (Kourou 2015, p.85, Figs 2, 3a-b.). Pottery imports found in Late Protogeometric contexts at Grotta and in the north Plithos cemetery were overwhelmingly Euboean (Charalambidou, et al. 2017, pp.113, 116; Kourou 2015, pp.89, 91-2.). The continuous burial evidence suggests that the settlement moved nearby, probably further inland and higher, away from the encroaching sea but this has not been archaeologically attested. ${ }^{13}$ Compared to the wide distribution of ceramics from nearby Paros, Naxian pottery found outside of Naxos is limited; found only in the surrounding Cyclades, Crete, and in Samos during the Geometric and Archaic periods (Charalambidou 2017, p.377.). Mainland Greek pottery imports are limited mostly to Attic and Euboean from the Late Protogeometric to Late Geometric (Charalambidou, et al. 2017, p.111; Vlachopoulos 2008a; 2008b; Lemos 2002, pp.27 ff.). Cist grave eleven from Mitropolis had two fine wheel made Attic imports and a coarse handmade Naxian jug (Charalambidou 2017, p.377, Figs 5a, 5b.). At Yria from the late $8^{\text {th }}$ through the $7^{\text {th }}$ century, Parian imports as well as local imitations of Parian pottery styles were plentiful. Euboean imports become less common after 700. East Greek imports at Yria from Rhodes and Samos begin from

\footnotetext{
12 Evidence from Koukounaries on Paros, Xobourgo on Tenos, and Ag. Spyridon on Melos may suggest continuity, but the evidence is equivocal.

${ }^{13}$ Lambrinoudakis 2004, pp.61-2 suggested the Protogeometric settlement moved just south to the hill of Kastro and is under the modern town.
} 
the end of the $8^{\text {th }}$ and continue into the $6^{\text {th }}$ century (Simantoni-Bournia 2002, p.278.). Corinthian imports become common after c. 800. At Middle Geometric Tsikalario, a Cypriot import was unearthed. There is debate as to whether this was an import, or an heirloom brought back to Naxos by a sailor involved in the Al Mina trade (Charalambidou 2017, p.377.). An intriguing example of diffusion are small terracotta birds, not commonly found in the Cyclades, yet twenty-six have been found on Naxos from burial contexts in Naxos Town and Tsikalario (Charalambidou 2018; 2017.). Other terracotta birds have been found on Cyprus, Rhodes, Samos, Crete (from the sanctuary of Hermes and Aphrodite at Syme Viannou), and in the Cyclades on Andros at Zagora, at Siphnos on the northeast slope of Chora, and in Delos (Charalambidou 2017, pp.384-6, Figs 11, 12.). The mix of pottery forms and motifs seen in imports from the $8^{\text {th }}$ century onwards argues for an expansion of interconnectedness (Charalambidou 2017, pp.383, 387-8; Charalambidou, et al. 2017, pp.109-111; Coldstream 2009, pp.165-71; 1983, p.18.).

Andros and Tenos form the northern boundary of the Cyclades. Evidence of contact with Euboea is considerable. Crielaard and Songu suggest that the Karystia area of southern Euboea is more closely identified with the Cyclades than the rest of Euboea from which it is separated by the massif around Mt. Ochi (Crielaard \& Songu 2017, p.276.). On Andros, inhabitants from two Geometric settlements merged around 700 BCE to form a polis at Palaeopolis (Hall 2014, pp.78-81, 85.). One of the infrastructure projects undertaken at Palaeopolis was the construction of a significant harbour mole. The harbour facilities merged with a defensive wall and were backed by an agora (PalaiokrassaKopitsa 2012, p.32, Figs 3, 4, 5.). The location was perfectly suited to capture maritime trade activity passing by (Kotsonas 2012, p.250; Palaiokrassa \& Vivliodetis 2008, p.139.).

Thera marks the southern extent of the Cyclades and is the closest island to Crete with which the evidence suggests a trading network developed. Thera's connection with Crete is best demonstrated in pottery distributions (Erickson 2010). Belly-handled amphorae moved from Athens to the Cyclades and on to Crete in the Early and Middle Geometric periods (Whitley 2015, p.108.). They are found on the mainland in Athens and the Argolid, in the Cyclades at Naxos and Thera (plus a fragment at Delos) and in Crete at Knossos. ${ }^{14}$ In Thera, a nearly complete Attic belly-handled amphora was found in grave

\footnotetext{
${ }^{14}$ On Cycladic material in Knossos see Coldstream 2006; 1996; 1990.
} 
29 in the northern cemetery at Mesavouno. Imitations of the design came from grave 18 in the south cemetery at Perissa (Whitley 2015, pp.115-6.). Finds from the Sellada cemetery dated to the mid- $7^{\text {th }}$ century and included a range of items from various provenances including two silver rings with Egyptian (or pseudo-Egyptian) scarabs and Phoenician glass beads. Ceramics were mostly local, but with imports from Corinth, Crete, and Cyprus. A late $6^{\text {th }}$ century grave complex from the same cemetery contained four pyre pits with Attic black figure cups (Zaphiropoulou 1971, pp.226-30; Sheedy 2006, p.62.).

Parian Aa, wheel group, and Melian-ware was found on Thera, at Itanos in eastern Crete, and at Tocra, suggesting a north to south trade route (Paspalas 2012, p.80; Papadoupoulos \& Smithson 2002, pp.163-6, 175, 178-9; Sheedy 2005, pp.188-9.). Cycladic pottery has been found in Crete at Azoria and Olous, and Cycladic one-handled cups were common in cemetery contexts such as the extra-urban sanctuary at Vamies near Itanos in the later $6^{\text {th }}$ century (Erickson 2011, pp.388-9; 2010, pp.40-1, 77-86, 231, 28791, Fig. 9.30; Coldstream et al. 2001, pp.23, 87.). Common types found at Itanos are skyphoi and cups with painted dots for decoration like those found at Despotiko (Erickson 2010, p.294, n126.). The ceramic evidence supports the establishment of a trade route in the $6^{\text {th }}$ century from the Cyclades to Crete, passing through Thera and Itanos as the two hubs. From Itanos, Cycladic traders could move south to North Africa or southeast to Egypt, then work their way up the Levantine coast to northern Syria and then back west to the Cyclades (Viviers \& Tsingarida 2014, pp.169-73; Erickson 2010, pp.233, 284, Fig. 11.1, n72; Vivers 2009.).

The north to south trade perhaps underlies Herodotus's (4.150-165) stories of the Therans founding colonies in North Africa at Plateia and Cyrene. Herodotus described a delegation of Therans wandering fruitlessly about Crete seeking information on Libya. Eventually, they came to Itanos where they met the murex fisherman Korobios who became their guide.

The sacred island of Delos was the recipient of countless dedications from throughout the Hellenic sphere. On Delos, the small Late Bronze Age settlement seems to have been abandoned in Late Helladic IIIB as Late Helladic IIIC evidence is not extant (Mazarakis Ainian 1997, p.329.). This is earlier than the Late Helladic IIIC abandonments seen elsewhere such as Ayia Irini on Keos, Phylakopi on Melos, and Aghios Andreas on Siphnos. Evidence of habitation on Delos is not seen again until late in the $9^{\text {th }}$ century (Ibid.). By the Late Geometric period, the sanctuary had grown in importance evidenced 
by the construction of the Pre-oikos of the Naxians, the Temple of Artemis, and the small chapel to Hera on Mt. Kythnos, all constructed c. 700 or slightly later (Temple Gamma may predate these structures), (Mazarakis Ainian 1997, pp.179-83, 329.). Only Cycladic and Attic pottery has been found at Delos prior to $c .750 .{ }^{15}$ By $c .700$ this had changed (Coldstream 2003, p.215.). Significant volumes of pottery from Paros, Naxos, and Rhodes have been found on Delos as well as some finds from Euboea, Corinth, Cyprus, and notably, some from Crete. Delos was the recipient of dedications and offerings reflective of the growing economic capacity in the Greek world by the Late Geometric period. Greek societies were able to generate excess wealth enabling them to make dedications. Delos was a benefactor of the increasing economic output of other Cycladic islands and elsewhere.

The island of Keos (modern Kea) appears to have been nearly abandoned following the Bronze Age. Yet, sporadic finds in Temple A in the abandoned Bronze Age site of Ayia Irini suggest there was early Iron Age activity on the island (Gounaris 2005, pp.212, 29-30.). Shrine BB was built in Room Six where Protogeometric and Geometric period pottery sherds were found on the floor (Caskey 1998, p.127, Figs 11, 23, n16; Gounaris 2005, Fig. 4.). A shrine in Room One, noted for a stone head found in a ring stand, was dated to the Geometric period. This shrine continued in use to c. 500 (Caskey 1998, p.127.). Most of the imported pottery is Athenian but there are exceptions such as a Naxian pot from second half of $8^{\text {th }}$ century, and a deposit of miniature Corinthian skyphoi. Later than many of the other Cycladic islands, significant repopulation is not evident until the $6^{\text {th }}$ century when four independent poleis (Koressos, Ioulis, Poieessa, and Karthaia) were founded (Mendoni 1994, p.150.). Evidence of connectivity is robust thereafter. Pottery imports from Attica, Corinth, Paros, Melos, and Siphnos are widely found in surveys (Sutton 1991, pp.245, 252, Fig. 5.2; Mendoni 1994, pp.150, 152, 154.). Evidence of miltos extraction and export to Athens is preserved both archaeologically and by $4^{\text {th }}$ century epigraphic evidence. ${ }^{16}$

On neighbouring Kythnos, an undisturbed adyton from an Archaic temple located on the middle terrace of Vrykastro was found (Mazarakis Ainian 2019; 2005, pp.90-3.). The finds come from wide-ranging provenances suggesting significant foreign contact.

\footnotetext{
${ }^{15}$ One is tempted to suggest a correlation with the new construction and the Homeric Hymn to the Delian Apollo referred to earlier.

${ }^{16}$ Theophrastus De Lapidibus 8.52; IG ii 1128. Cherry, Davis, \& Mantzourani 1991, pp.299-300.
} 
Ceramics from the adyton included Parian, Chian, East Greek bird bowls, Corinthian, and Attic black glazed items. ${ }^{17}$ Jewellery finds consisted of amber, carnelian, rock crystal, glass paste, faience, and semi-precious stones belonging mostly to necklaces and often with incised representations, one of which was a Late Bronze Age ship. Also found were scaraboids, seals and gems, bone and ivory discs (with sphinx and goat motifs inscribed), as well as a few Egyptian scarabs belonging to $22^{\text {nd }}(945-713)$ and $26^{\text {th }}(664-525)$ Dynasties. Metal finds were the largest category from inside the adyton. There were about 100 iron and 450 bronze objects recovered. Fibulae suggesting island, Boeotian, and Phrygian origin as well as myriad small pieces were unearthed. More than 120 silver and 75 gold jewels in the forms of fibulae, pins, earrings, rings, rosettes, amulets, and pendants were present (Mazarakis Ainian 2005, pp.96-9 and Plates.). Most of the finds date to $7^{\text {th }}$ and $6^{\text {th }}$ centuries, but there are Protogeometric and Early Geometric pieces which, like the Bronze Age pieces, were probably heirlooms (Koutsoumpou 2017; Mazarakis Ainian 2005, p.99.).

Melos (modern Milos) was rich in mineral resources and the Melians had a robust trade throughout antiquity of its many and varied mineral resources (Shelford 1982, pp.74-81.). Other than the obsidian which can be chemically identified, three other mineral exports did not leave a traceable trail for the most part. Alum (a hydrated sulphate of aluminium) was used in dyeing and tanning. Kaolin (a hydrous silicate of aluminium) had three uses: whitening and thickening cloth, in ceramics, and for cosmetics. Abrasives such as pumice were mined and exported from Melos throughout antiquity. ${ }^{18}$ Ceramic exports however are not plentiful and are found only on the near islands of Kimolos and Siphnos and at Tocra in North Africa. 'Melian Ware' most commonly produced as a large krater/amphora, seems to have been first produced on Paros c. 680 and later Melos. Melian ware was widely exported, and examples have been found at Tocra and on the Thracian coast opposite the Parian colony at Thasos, founded c. 680 (Paspalas 2012, p.81.).

\footnotetext{
${ }^{17}$ Koutsoumpou 2017 discussed the ceramics in detail, she noted (p. 165) there are no finds from Naxos suggesting Kythnos was under some type of Parian zone of influence; Mazarakis Ainian 2005, p.96.

18 Alum and Kaolin (Melian Earth) are mentioned by Pliny the Elder, Naturalis Historia, 33.65, 88, 94-8; 34.106, 116; 35. 183-8; 36. 154-6; Dioscorides De Material Medica, 5.114, 171-9; Theophrastus de Lapidibus, 9.62. McGilchrist 2010(19), pp.233-6 and Renfrew 1982, pp.275-8 both give a concise description of the various minerals that were mined and their uses; see also Pittinger 1975.
} 
Evidence of connectivity is also apparent on Amorgos, Kimolos, Siphnos, and Tenos. ${ }^{19}$ On many of the other Cycladic islands such as Anaphe, Folegandros, Ios, Mykonos, Rhenia, Seriphos, Sikinos, Syros, and the islands known as the Lesser Cyclades evidence of contact beyond the island during the Iron Age is sporadic at best. Space limitations preclude an extensive discussion of every island.

The archaeological record provides abundant evidence of intra-island connectivity as well as connectivity with distant locales such as mainland Greece, Egypt, the Levant, and North Africa. Moreover, the location of finds includes both final destinations such as sanctuary deposits and grave goods as well as items more logically attributed to through trade such as the belly handled amphorae and drinking shapes with dotted decorations. Evidence of long-distance trade in natural resources such an minerals and marble are compelling. The evidence has both depth and breadth to it suggesting Cycladic societies on many of the islands were well connected with others, both near and far, by the Late Geometric and on into the Archaic period.

\section{Impact of Climate}

The Cycladic islands lie in an area of very low precipitation. To the east of the Cyclades, in the Keramic Gulf region of Anatolia to the east of Bodrum (Halicarnassus), annual precipitation is around 1,250 millimetres $(\mathrm{mm})$ per year. ${ }^{20}$ To the west, at Elis in the western Peloponnesus, rainfall averages around 1,100 mm annually (Bresson 2016, Fig. 2.4.). In the Cyclades though the average rainfall is about $400 \mathrm{~mm}$, less than onethird the precipitation in Anatolia. See data from selected locations in Table 1 below:

\footnotetext{
${ }^{19}$ On Amorgos, only Minoa has been systematically excavated, see Marangou 2005; 2002. Kimolos has kaolin quarries (also called Kimolian Earth by Strabo Geog. 10.5.1) at the northern end, see Pantou and Ditsa 2011; Coldstream 2003. On Siphnos, silver and gold mines were exploited in the Iron Age, see Hdt. 3.57; Pausanias 10.11.2; Brock and Mackworth Young 1949; Televantou 2017; 2008. On Tenos, Xobourgo is an intriguing site, see Kourou 2015; 2011, 2002.

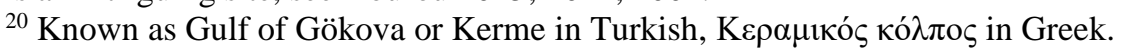




\begin{tabular}{|l|l|l|l|}
\hline \multicolumn{4}{|l|}{ Rainfall per Year in Millimetres for Selected Greek Locations } \\
\hline Mytilini & 648 & lerapetra, Crete & 662 \\
\hline Samos & 709 & Rethymno, Crete & 777 \\
\hline Naxos & 366 & Tripoli, Peleponnese & 781 \\
\hline Milos & 411 & Kalamata, Peleponnese & 780 \\
\hline Zakinthos & 943 & Athens & 365 \\
\hline \multicolumn{4}{|l|}{} \\
\hline Reference: Hellenic National Meteorological Service \\
\hline Available at: www.currentresults.com/Weather/Greece/ \\
average-yearly-precipitation.php. Accessed 7 Jan. 2021. \\
\hline
\end{tabular}

Table 1

Besides rainfall not being plentiful, there is no guarantee that passing rain showers are going to fall on a specific island or in an area where fields of individual interest are located. A personal story highlights this point: We are fortunate to own a small farm on the island of Paros. We have about fifteen olive trees from which we produce olive oil. Olive trees produce a crop every two years (not annually). In 2017, the winter rain was just twenty percent of normal, a micro-climate event. This had a severe impact on the olive production in what would have been the biennial good harvest year. The timing of the drought meant that we went four years between harvests of enough olives to produce oil. For an ancient society that depended on olive oil for both fuel and nutrition, the timing of the drought would have been a major setback.

Ongoing excavations on Naxos at the island-like headland of Stelida, to the southwest of Chora, are uncovering Mesolithic occupation levels much earlier than any prior evidence would indicate for Cycladic occupation (Sfyroera 2018, p.328.). Prior to these discoveries, the earliest human habitation evidence was found on Kythnos at Maroulas dated to Late Mesolithic $8^{\text {th }}$ millennium where human burials, a house floor, and some circular structures have been found (Dawson 2014, p.174, Table 6.2.). Habitation evidence found on the larger islands dates to the $5^{\text {th }}$ millennium when seventeen of the islands were first inhabited, about $60 \%$ of the archipelago. Habitation spread to other islands over the next two millennia with most islands inhabited by the $3^{\text {rd }}$ millennium (Dawson 2014, pp.164-6, Fig. 6.19.). Compared to other Mediterranean 
island groups, this is late, especially considering the proximity to the mainland. ${ }^{21}$ Speculatively, perhaps the relative lack of rainfall on these islands made agriculture difficult and consequently the islands were unattractive for settlement.

The low rainfall in the Cyclades has the ancillary impact of sparse natural vegetation. The lack of vegetation results in a lack of organic material that over time degrades into soil. Consequently, not only are the islands lacking in precipitation they are also barren compared to better watered regions such as Crete. ${ }^{22}$

James Bent toured the Cycladic islands in two winters of the early 1880s. His primary purpose was to record the manners and customers of the islanders (Bent 1885, p.v.). Bent related several stories regarding drought. On the island of Folegandros, when sensing a drought, the entire population of the island would march in procession together with the priests carrying icons of the Panayia to the top of Mt. Prophet Elias where they would kneel en masse and pray for rain. They would then continue the procession to the shrine of Ag. Eleutherios and repeat the prayers (Bent 1885, p.203.). In the 1880s, long before mass-tourism, Bent recorded that Therians frequently had to import drinking water from other islands and similarly on Syros, at times drinking water was delivered door to door by cart (Bent 1885, pp.122, 305.).

One of the possible remediation strategies for islanders during times of drought, was to develop robust networks of communication with other areas. These areas may have been able to provide food supplies when those from the home islands were inadequate. I suggest that one of the explanations for the abundant evidence of wide-ranging connections with other areas described above, was just this - to establish robust connections for safety if nothing else. The development of trade goods such as marble and other mineral resources would have provided the wealth to exchange for needed supplies. Unfortunately, reaching back over 2,500 years to a period in which writing had been lost, it is impossible to definitively know what individual motivations were. The evidence suggests areas of correlation but that is not the same as causation. Consequently, the proposals put forth herein must be treated as speculative. Describing why people did what they did, we can only go so far as to suggest a correlation between environmental

\footnotetext{
${ }^{21}$ See Dawson 2014 on other island habitation: Cyprus 11,000-9,000 BC p.140, Crete 130,000 BP p.136, Corfu 7,000 BC p.126, Brač 7,000 BC p.121, Corsica 9,000 BC p.87. Crete is the outlier with evidence for significantly earlier habitation, see Strasser et al. 2010.

${ }^{22}$ Deforestation for ship building and fuel are complicating factors.
} 
factors, food supplies, and the development of trade goods. ${ }^{23}$ That being said, concluding that an area with poor rainfall and the consequent insecurity of food production engaging in trade should not be surprising given the example of Athens (See Table 1) where some of the steps taken by the Athenians to secure food supplies are preserved in the written record. Solon urged Athenians to produce olive oil and wine, crops which required less rainfall to grow than did grain and trade those products for grain from areas that were able to produce grain at higher yields than Attica. ${ }^{24}$ Lysias 22 (Against the Corn Dealers) reveals Athenian angst about food supply and price manipulation in the early $4^{\text {th }}$ century BCE was acute.

\section{Weather Conditions as an Isolating Factor}

A complicating factor in the establishment of strong maritime based networks is that weather conditions in the Cyclades are not always suitable for maritime travel. Bent describes several instances of being stranded due to high winds during his travels. He was stuck on Sikinos, Milos, and Naxos. Traveling by steamer, not caique, from Milos to Syros, they had to seek refuge at Siphnos for two days while enroute for protection from the weather. A journey of only $95 \mathrm{~km}$ took nearly a week (Bent 1885, pp.80-81, 172, 177 8, 339.). Bent recounts a charming story of leaving Folegandros for a short sail to Antiparos, a distance of about $40 \mathrm{~km}$. A west wind came up from a dark cloud and they changed course to Amorgos, the wind continued to build so they changed course for Ios, but they could not make it around the north side of Sikinos due to wind and wave conditions, so they headed back towards Folegandros from whence they started. The wind direction made this course no longer tenable, so they bore off for Santorini. They adjusted course once again and skirted the south coast of Sikinos eventually making it to Ios. Bent commented "it is not where you will go, but where you can get" (Bent 1885, pp.207-8.).

Connectivity amongst islands has become a popular area of scholastic inquiry, often in association with network theory. ${ }^{25}$ The islands are close enough to one another that navigation by sight is possible. Broodbank proposed a network of connectivity in the Cyclades structured around the length of a day's voyage utilizing Early Bronze Age

\footnotetext{
${ }^{23}$ See Manning 2018 for a compelling discussion on the need to consider environmental factors in historical analysis.

${ }^{24}$ See Bresson 2016, pp.120-9 on the environmental conditions for grain, oil and wine production as well as Van Wees 2013, pp.450-2, 457-60. See Van Wees 2013, p.463 on Solon's trade prohibitions; Solon F65, Meiggs and Lewis 1988, $30=$ Fornara 1983, 63; Plut. Sol. 24.1.

${ }^{25}$ See Manning 2018, pp.234-5, 252-5; Knappett 2011; Malkin 2011; Broodbank 2008, pp.63-7, Fig. 3.4. 
technology of paddled transport. This brought most every island in contact with one another with just a few days paddling (Broodbank 2000, pp.105, 341-9; Dawson 2014, pp.36-8; Cunliffe 2008, p.51, Fig. 2.12; Cherry 1990.). With the development of sail in the Aegean, the entire archipelago could be transited in a couple of days under favourable conditions. This understanding was used to develop the thought that the Cycladic islands may have been more connected to one another than being separated by water might suggest (Dawson 2014, pp.128-31, Table 5.4; Broodbank 2013, Figs 7.31, 9.1; 2000; Malkin 2011; Constantakopoulou 2007; Horden and Purcell 2000, pp.123-171. See also Sheedy 2006, pp.15-16.).

Generally missing from this analysis though is the impact of weather. ${ }^{26}$ Wind roses are diagrams developed to give a pictorial representation of wind direction over time (see Fig. 1). The longer the line radiating from the centre, the more days (of the period under analysis) the wind blew from that direction (number in centre represents days of calm during the period). Consider Figure 1, an island located to the north or northwest would be near impossible to reach against the dominant winds in July. In April and October, when the prevailing wind direction was more varied, islands to the north would become accessible again. Considering this real-life parameter, the connectivity between islands is weather dependent, i.e. not a constant. ${ }^{27}$

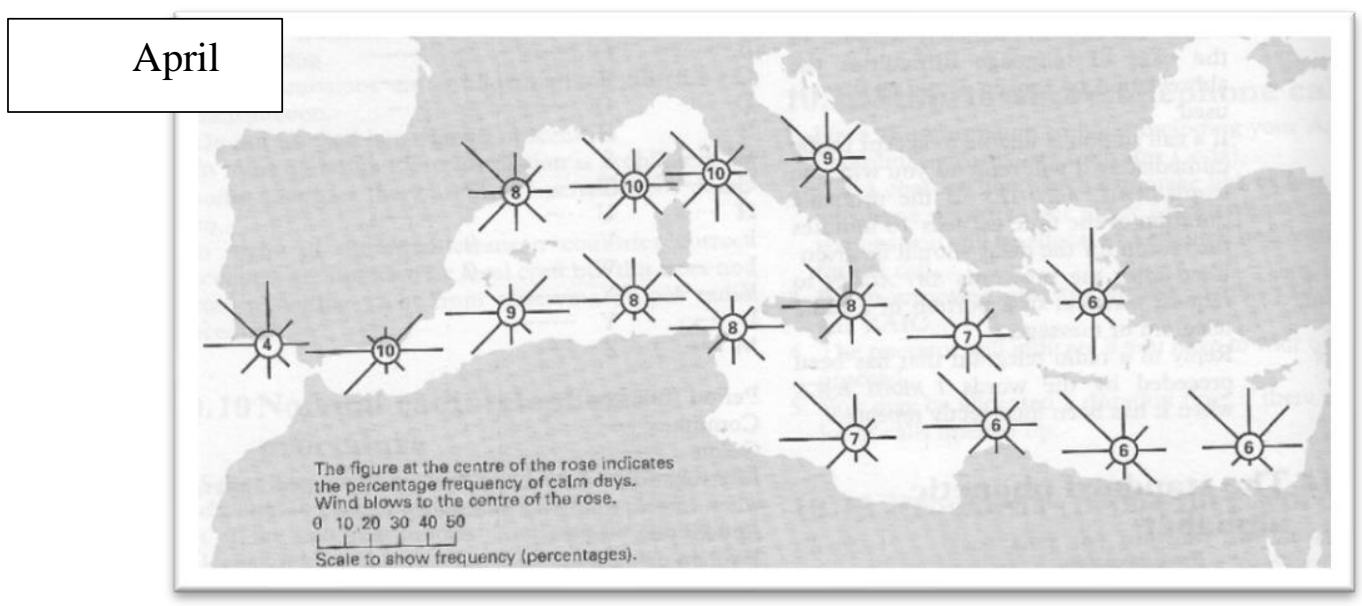

\footnotetext{
${ }^{26}$ Broodbank 2000, pp.92-6 discussed the impacts of wind and current on travel correctly noting that even in the summer season high winds can block voyages for extended periods. Heikell 2001, pp.27, 234 mentions Beaufort 7-8 force winds blowing continuously for two weeks in the Cyclades in July and August. ${ }^{27}$ Murray 1987 discussed whether modern winds equate with ancient winds. Based on a comparison of modern data with records compiled by Aristotle and Theophrastus, Murray concluded the modern and ancient wind data had strong correlation, especially for the Eastern Mediterranean.
} 
Mare Nostrum, ano 2021, v. 12, n. 2
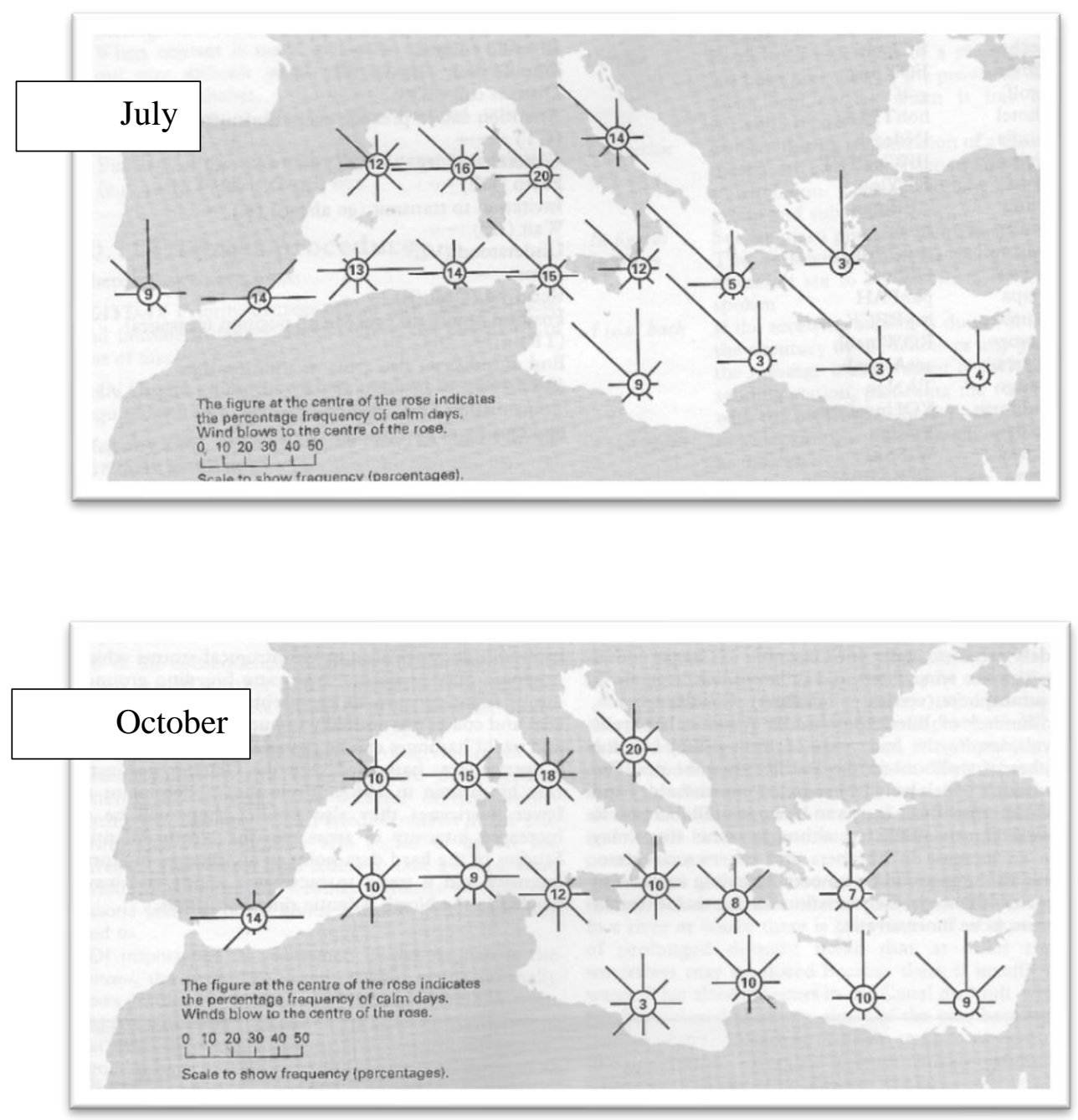

Figure 1: Wind Roses for April, July, and October (used by permission Rod Heikell, Mediterranean Cruising Handbook, 1998, Imray, pp. 110-111).

Bent noted the anthropomorphic quality of the winds. In Tenos, where the winds tend to be very strong, the northwind was termed 'Mr. North Wind' who was a dreaded visitor and in Thera where Bent encountered 'hurricane force winds and waterspouts' the wind was termed a 'tornado', caused by demons rushing about. The devil himself was often named 'the wind' (Bent 1885, pp.145, 265.). ${ }^{28}$

In the Roman period, the harshness of the Cycladic weather may have contributed to it being a place of exile. The orator Cassius Severus was banished to Seriphos, Caius Silanus to Kythnos, and Vibius Serenus to Amorgos as examples. ${ }^{29}$

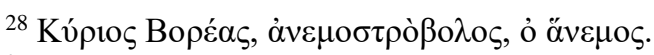

${ }^{29}$ Tacitus Annales, 4.21, 3.68, 4.13; see Sweetman 2016, pp.50-1.
} 
Winds in the central Aegean can blow with considerable force both during summer months and in winter storms preventing prudent maritime travel for weeks at a time. These conditions leave individual island populations isolated from one another with no certainty as to when conditions will change making travel again possible. This suggests creating buffer stocks of food and other necessities was a responsible social strategy.

\section{The Case of Crete}

A brief discussion on Crete is offered as a contrast to the patterns seen in the Cyclades. The purpose is to stimulate thought as space limitations preclude a definitive analysis. ${ }^{30}$

In contrast to the Cyclades and keeping in mind the plethora of items not preserved in the archaeological record, based on the extant evidence, Iron Age Crete appears not to have been quite as outward looking. Few Iron Age settlements were located on the coast; only Phalasarna, Kydonia, Kommos, Ierapetra, and Itanos (Viviers \& Tsingarida 2014, p.165.). Compared to the Cyclades, Iron Age contexts in Crete show less evidence of outside contact nor are Cretan origin items often found outside of Crete.

A few $11^{\text {th }}$ century Cypriot items were found in Crete. From grave 201 of the North Cemetery of Knossos, a fragmentary four-sided decorated bronze stand was uncovered, and Cypriot bronze tripod stands were found in mid- $10^{\text {th }}$ century mortuary contexts. ${ }^{31}$ Contact with Cyprus is further evidenced by black on red unguent vessels with a distinctive neck ridge at the handle attachment, usually found in a funerary context (Kotsonas 2011, pp.139-41 argues that these are locally produced imitations; Coldstream et al. 2001, pp.40, 42 argues for imports.). Also from Cyprus are animal shapes used as pitchers, especially bird shapes (Coldstream et al. 2001, pp.44.). Excavations of a tholos tomb excavated at Amari near Rethymon, produced a bronze amphoroid krater, an iron knife, a bronze fibula, a pin, and black-painted vase very similar to Cypriot black-slip ware (Kourou 2008, pp.363-4, Fig. 2.).

Near Eastern imports have been found at Knossos and Kommos in $10^{\text {th }}$ century contexts. ${ }^{32}$ A bronze bowl from Teke Tomb J, was inscribed with Phoenician writing (Kourou 2008, pp.365-6, Fig. 5.). Burial finds of gold jewellery of Phoenician design and

\footnotetext{
${ }^{30}$ Erickson 2010 provides a robust view of the evidence from Crete.

${ }^{31}$ Kourou 2008, p.363. Whether this item too is an heirloom, or a fresh import is unclear, similar Cypriot bronze stands have been found in $11^{\text {th }} \mathrm{c}$. contexts in Sardinia.

${ }^{32}$ Antoniadis 2017 gives an excellent summary.
} 
a Sardinian askos (juglet), plausibly a Phoenician import, from Teke Tomb 2 suggest Phoenician trade along the north coast of Crete. ${ }^{33}$ Material from Kommos suggests another Phoenician trade route existed along the south coast evidenced by finds of Phoenician transport amphorae and Phoenician pottery (Shaw \& Shaw 2000, pp.216, 2204, Plates 4.63, 4.64, material from temple phase A.). At Kommos c. 800, a temple was built seemingly for resident Phoenician traders (Papadopoulos 1997, p.193; Watrous 1998, p.75; Shaw 1982, p.185.). Evidence of contact is also found inland. At Eleutherna, from cemetery excavations, faience beads, molded glass phiale and a bronze bowl suggest contact with Cyprus, the Levant, and perhaps even Egypt (Stampolidis 1990, p.388.). Egyptian clay plaques and stonework has been found at Gortyn (Wallace 2010, pp.2225.). Temple architecture at Prinias suggests Egyptian connections (Watrous 1998.).

Cycladic pottery was found on Crete at Eleutherna, Knossos, Kommos, Azoria, and Olous (Erickson 2010, p.231; Coldstream et al. 2001, pp.23, 87; Shaw \& Shaw 2000, pp.219, 222-224, 228.). Shapes included elongated amphorae, belly handled amphorae, cups, skyphoi, oenochoe, pyxis, and Siphnian cooking pots which, with their bright red fabric, are notable (Coldstream et al. 2001, p.87.). The clay of Siphnos seems to have been particularly suited for cook-ware (Boileau \& Whitley 2010, pp.238-42.). As mentioned above, at Itanos, Cycladic imports from $6^{\text {th }}$ century contexts were found at the settlement cemetery and the extra-urban sanctuary Vamies (Erickson 2010, p.231.).

Looking beyond Crete, Late Geometric Cretan pottery exports are found almost only in the Cyclades, with remains primarily on Thera but with some finds on Melos, Andros, and Delos. There is only one Cretan vase found in Athens from this period. No Late Geometric period pottery from Crete has been found in the Levant, Cyprus or in the west until the founding of the colony at Gela in Sicily c. $689 .{ }^{34}$ The lack of evidence of Cretan exports is admittedly based largely on negative evidence and we must keep in mind the caution mentioned earlier that items not preserved in the archaeological record may have been exported.

The situation in Crete in the early Archaic period stands in stark contrast to the development seen on many of the Cycladic islands. Cycladic ceramics were distributed over a wide area including Egypt, the Levant, and the northern Aegean suggesting an expansive trade network. Cycladic finds at Al Mina date to the $10^{\text {th }}$ century while the

\footnotetext{
${ }^{33}$ Vagnetti 1989, pp.355, 358-60, n2, the stratigraphy of this tomb is disturbed, date range is 850-680.

${ }^{34}$ On Cretan pottery outside Crete see Coulié 2013, pp.233-5; Coldstream 2003, pp.288-9.
} 
earliest Cretan material at Tocra dates to $650-630 .{ }^{35}$ Parians and Naxians were quarrying marble, the Siphnians mining gold and silver and the Melians kaolin and other minerals in the $7^{\text {th }}$ century. In Crete, there is only minimal evidence of similar kinds of development. Cretan ceramics are not widely distributed. No imports of Geometric ceramics from Crete have been found at Al Mina or vicinity, though there have been some found on Cyprus in burial and sanctuary contexts (Luke 2003, on Al Mina p.58, on Cyprus pp.42, 44.). Numismatic evidence shows ten Cycladic poleis were minting coins from 540, as much as 70 years earlier than in Crete where the evidence suggests the first coins were minted c. 470 (Sheedy 2006, p.51, Table 1, 3; Stefanakis 1999, pp.249-51.).

Marble resources in eastern Crete existed but were not exploited. ${ }^{36}$ One small quarry has been identified west of modern Siteia where marble was quarried sometime in the Classical and Hellenistic period. Platon identified $7^{\text {th }}$ and $6^{\text {th }}$ century pithoi fragments in the area but it is unclear if they were in association with the quarry (Platon 1954, p.156.). Durkin and Lister were unable to date the quarry beyond saying it was Greek, not Roman. They suggest the closest parallel is with tool marks and quarrying techniques seen around the Pnyx in Athens dated to the $4^{\text {th }}$ century (Durkin \& Lister 1983, pp.69-70, $83, \mathrm{n} 7$.). This creates the impression that the conservative Cretans were warry and reticent of venturing far from home. ${ }^{37}$ The Cycladic evidence suggests a coming together of multiple developments; social, economic, and entrepreneurial in the Iron Age Cyclades that did not manifest themselves in Crete.

\section{Cretan Geography and Precipitation}

Crete is the largest island in Greece with an area of 8,312 sq. km, $240 \mathrm{~km}$ in length, $48 \mathrm{~km}$ at its greatest width and just $12 \mathrm{~km}$ wide at its narrowest. The island is divided by significant mountain groups into zones (Sweetman 2013, p.10; Whitley 2013, pp.275-6; Wilson 2008, pp.77-9.). The White Mountains comprise the bulk of western Crete with several peaks near 2,400 m extending shear from the south coast, to Kydonia in the north, and almost to Eleutherna in the east. These rugged mountains seem to have limited

\footnotetext{
35 On Al Mina see Vacek 2017, p.49; Boardman 1996, p.157 on Al Mina date; On Tocra see Shaw 1982, pp.190-1. See Coldstream 2003, pp.215, 228 on Cycladic finds.

36 See Kneuker, Dörr, Petschick, and Zulauf 2015, pp.359-60, Figs 3-5, 10 on marble resources in the Mirabello Bay area near Olous, Vrokastro, and Azoria; Seidel 2003, p.77 on marble near Lato; Barker 1976, pp.366, 371 on marble strata on the island of Mochlos near Azoria and on the southern shore of Mirabello Bay.

${ }^{37}$ See Erickson 2010, pp.15-19 on Cretan conservatism generally.
} 
habitation to the northern coastal plain (Nixon, et al. 1988.). The central section is dominated by Mt. Ida, 2,456 m, the highest point on the island, two and a half times higher than the tallest Cycladic island Naxos, at just under 1,000m. The central massif divides north from south as well as east from west; the area around Knossos to the north and the fertile Mesara to the south are connected by multiple overland routes running either side of Mt. Ida. The eastern end of the island is split by two mountain groups: the area around Mt. Dikte $(2,148 \mathrm{~m})$ and the Thrypti (or Siteia) range $(1,476 \mathrm{~m})$ east of the Ierapetra isthmus, the narrowest part of the island. Within this mountain group is the high fertile plain of Lasithi, c. $900 \mathrm{~m}$. The high mountains are covered with snow in the winter. ${ }^{38} \mathrm{In}$ the spring, the run-off of snow-melt waters the high mountain plains such as Lasithi and Nidha as well as littoral plains via seasonal rivers and streams (Pendlebury 1965, pp.56.). Springs were an important source of water for settlements and may have influenced site location (Nowicki 2000, pp.25-6.).

Crete is nearly twenty times larger than Naxos, the largest Cycladic island, 428 sq. $\mathrm{km} .{ }^{39}$ Crete is larger, more mountainous, better watered, and more climatically diverse than any of the Cycladic islands. Speculatively, Crete was large enough that the island's resources could support its own population's needs. From Table 1, the average rainfall on Naxos and Milos is 54 percent that of the average rainfall at Ierapetra and Rethymon. The need for Cretans to look beyond their island was not the same as for the Cycladic islanders. There was less environmental risk in the meteorology of the Cretan environment. Snowpack on the high mountains released its water slowly, lasting well into the spring, unlike rainfall which quickly dissipates, adding a buffer that the Cyclades did not have.

\section{Conclusion}

The evidence indicates that some of the Cycladic islanders created robust interisland and distant maritime networks while the Cretans did not develop distant networks of similar depth. This suggests that insularity for the two regions was different. The array of archaeological evidence for both imports and exports suggests that Cycladic islanders

\footnotetext{
${ }^{38}$ From personal experience: snow patches on Mt. Ida last as late as early May, the Lasithi plain had over one meter snow depth in the winter of 2001-2. In the Cyclades, Andros and Naxos can see some snow occasionally, but in both cases the accumulation is miniscule compared to Crete; Heikell 2001, p.476.

${ }^{39}$ Area references from McGilchrist 2010(17) Naxos and Pugsley 2010 Blue Guide Crete.
} 
were less insular than the Cretans. Evidence also indicates that the two regions had different environmental scenarios especially as regards precipitation. Most likely this had an impact on food productivity and more so on the security of food productivity over the longue durée. This paper proposes that the Cycladic islanders developed stronger networks in part as a response to food security issues. Reciprocally, the Cretans did not have the same food supply risks due to better rainfall and soil conditions, consequently they were comfortable with a more insular approach. It is suggested that the relative rainfall between the Cyclades and Crete was a factor, emphatically not the sole factor, but one of a myriad of issues that may help to explain the more outward looking connections that the archaeological evidence suggests the Cycladic islanders pursued compared to the more stay at home Cretans. Insularity in this interpretation is a variable factor, not a constant, and degrees of insularity can be observed, it is not an all or nothing proposition. Cycladic islanders in the Iron Age appear to have been less insular that their contemporaries in Crete. The insularity and connectedness of the two regions were not the same.

Article received in: 01/05/2020

Approved in: 02/05/2021 
Mare Nostrum, ano 2021, v. 12, n. 2

\section{BIBLIOGRAPHIC REFERENCES}

Antoniadis, V. (2017). Knossos and the Near East, A contextual approach to imports and imitations in Early Iron Age tombs. Archaeopress, Oxford.

Barker, M. (1976). 'Soft-Stone Sources on Crete.' Journal of Field Archaeology. Vol. 3, No. 4. (pp.361-74).

Bent, J. T. (1885). The Cyclades or Life Among the Insular Greeks. Longmans, Green, and Co., London.

Boardman, J. (1996). 'Euboeans Overseas: A Question of Identity.' In Evely, Lemos, \& Sherratt (Eds.) Minotaur and Centaur, Studies in Archaeology of Crete and Euboea, presented to Mervyn Popham, BAR International Series 636. Oxford, (pp. 155-60).

Boardman, J. (2006). 'Greeks in the East Mediterranean, (South Anatolia, Syria, Egypt).' In Tsetskhladze (Ed.) Greek Colonization, An Account of Greek Colonies and Other Settlements Overseas, Vol. 1. Brill, Leiden, (pp. 507-34).

Brock, J.K. and Mackworth Young, G. (1949). 'Excavations in Siphnos.' The Annual of the British School at Athens. No. 44, (pp. 1-92).

Boileau, M. \& Whitley, J. (2010). 'Patterns of Production and Consumption of Coarse to Semi-Fine Pottery at Early Iron Age Knossos.' The Annual of the British School at Athens. No. 105, (pp; 225-68).

Bresson, A. (2016). The Making of the Greek Economy; Institutions, Markets, and Growth in the City-States. Princeton University Press, Princeton and Oxford.

Broodbank, C. (2000). An Island Archaeology of the Early Cyclades. Cambridge University Press, London.

Broodbank, C. (2008). 'The Early Bronze Age in the Cyclades.' In Shelmerdine (Ed.) The Cambridge Companion to the Aegean Bronze Age. Cambridge University Press, Cambridge, (pp. 47-76).

Broodbank, C. (2013). The Making of the Middle Sea, A History of the Mediterranean from the Beginning to the Emergence of the Classical World. Thames and Hudson, London.

Bruno M., Lazzarini L., Soligo M., Turi B., \& Varti Matarangas, M. (2010). 'The ancient quarry at Karavos (Paros) and the characterization of its marble,' In Schilardi \& Katsonopoulou (Eds.) Paria Lithos, Parian Quarries, Marble and Workshops of Sculpture. The Paros and Cyclades Institute of Archaeology, Archaeological and Historical Studies, 1. Athens, (pp. 95-103). 


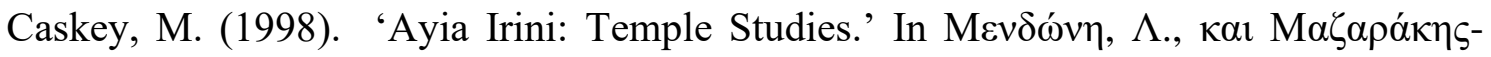

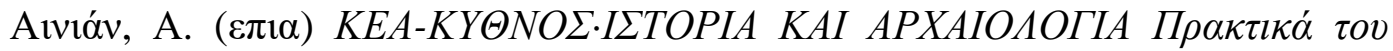

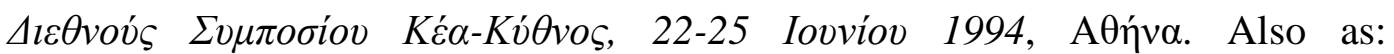
MEAETHMATA 27, Research Centre for Greek and Roman Antiquity, National Hellenic Research Foundation, Paris, (pp. 123-38).

Charalambidou, X. (2017). 'Ceramics, cultural interconnections and influences on

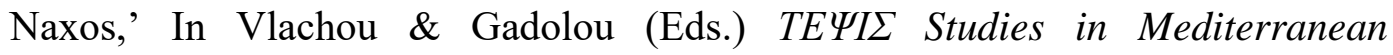
Archaeology in Honour of Nota Kourou. CReA-Patrimoine, Brussels, (pp. 375-92). Charalambidou, X. (2018). 'Iron Age Mortuary Practices and Material Culture at the Inland Cemetery of Tsikalario on Naxos: Differentiation and Connectivity.' The Annual of the British School at Athens. No. 113, (pp. 143-198).

Charalambidou, X., Kiriatzi, E., \& Müller, N. (2017). 'Scales of Ceramic Analysis on Naxos (Cyclades).' In Handberg \& Gadolou (Eds.) Material Koinai in the Greek Early Iron Age and Archaic Period. Monographs of the Danish Institute at Athens, Vol. 22. Acts of an International Conference at the Danish Institute of Athens, 30 January - 1 February 2015. Aarhus, (pp. 109-32).

Cherry, J. (1990). 'First Colonization of the Mediterranean Islands'. Journal of Mediterranean Archaeology 3, (pp. 145-221).

Cherry, J., Davis, J., \& Mantzourani, E. (1991). 'Landscape, History, and Archaeology.' In Cherry, Davis, \& Mantzourani. Landscape Archaeology as Long-Term History, Northern Keos in the Cycladic Islands, From Earliest Settlement until Modern Times. Monumenta Archaeologica, Vol. 16. Institute of Archaeology, U.C.L.A. Los Angeles, (pp. 57-67).

Coldstream, J.N. (1990). 'Cycladic and Euboean Imports in the North Cemetery ay Knossos.' In Descoeudres (Ed.) EYMOY IIA: Ceramic and Iconographic Studies in Honor of Alexander Cambitoglou, MeditArch, Supplement No. 1. Sydney, (pp. 2530).

Coldstream, J.N. (1996). 'Knossos and Lefkandi: The Attic Connection.' In Evely, Lemos, \& Sherratt (Eds.) Minotaur and Centaur, Studies in Archaeology of Crete and Euboea, presented to Mervyn Popham. BAR International Series 636. Oxford, (pp. 133-46).

Coldstream, J.N. (2003). Geometric Greece, 900-700 BC, Second Edition. Routledge, London. 
Mare Nostrum, ano 2021, v. 12, n. 2

Coldstream, J.N. (2006). 'Potter and Painter in Geometric Knossos: The Attic

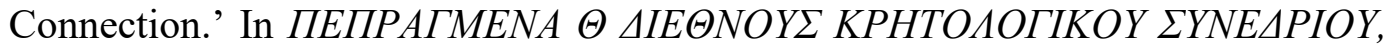

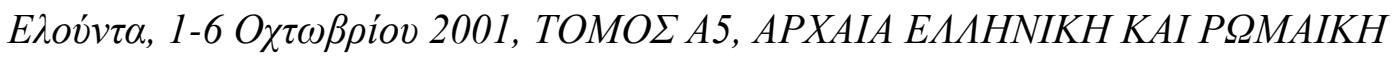

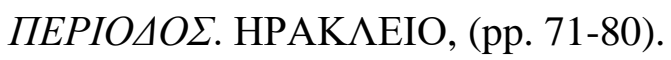

Coldstream, J.N. (2009). Greek Geometric Pottery, A survey of ten local styles and their chronology, Updated Second Edition. Methuen, Exeter.

Coldstream, J.N., Eiring, L.J., \& Forster, G. (Eds.) (2001). Knossos Pottery Handbook, Greek and Roman. British School at Athens Studies 7. London.

Constantakopoulou, C. (2007). The Dance of the Islands, Insularity, Networks, the Athenian Empire and the Aegean World. Oxford University Press, Oxford.

Constantakopoulou, C. (2018). 'Cycladic Archaeology and History: Some Thoughts.' In Angliker \& Tully (Eds.) Cycladic Archaeology and Research: New Approaches and Discoveries. Archaeopress, Oxford, v-xii.

Coulié, A. (2013). La Céramique Grecque aux époques géométrique et orientalisante. Picard, Paris.

Craik, E. (1980). The Dorian Aegean. Routledge \& Kegan Paul, London, Boston, and Henley.

Crielaard, J.P. \& Songu, F. (2017). 'Connectivity and Insularity in $1^{\text {st }}$-millenium southern Euboea: The Evidence from the sanctuary of Karystos-Plakari.' In Tankosić, Mavridis, \& Kosma (Eds.) An Island Between Two Worlds, The Archaeology of Euboea from Prehistoric to Byzantine Times. Papers and Monograms of the Norwegian Institute at Athens, Vol. 6. Athens, (pp. 275-83).

Cunliffe, B. (2008). Europe Between the Oceans 9000 BC-AD 1000. Yale University Press, New Haven.

Dawson, H. (2014). Mediterranean Voyages, The Archaeology of Island Colonization and Abandonment. Left Coast Press, Walnut Creek.

Durkin, M.K. \& Lister, C.J. (1983). 'The Rod of Digenis: An Ancient Marble Quarry in Eastern Crete.' The Annual of the British School at Athens. Vol. 78, (pp. 69-96).

Draganits, E. (2009). 'The Archaic Sanctuary on Despotiko Island (Cyclades): Geological Outline and Lithological Characterization of the Building Stones, with their Possible Provenance.' Austrian Journal of Earth Sciences. Vol. 102, No.1, (pp. 91101).

Erickson, B. (2010). Crete in Transition, Pottery Styles and Island History in the Archaic and Classical Periods. Hesperia Supplement 45. Princeton. 
Erickson, B. (2011). 'Public Feasts and Private Symposia in the Archaic and Classical Periods.' In Glowacki \& Vogeikoff-Brogan (Eds.) इTEГA: The Archaeology of Houses and Households in Ancient Crete. Hesperia Supplement 44. Princeton, (pp. 381-91).

Gounaris, A. (2005). 'Cult places in the Cyclades during the Protogeometric and Geometric periods: their contribution in interpreting the rise of the Cycladic poleis.' In Yeroulanou \& Stamatopoulou (Eds.) Architecture and Archaeology in the Cyclades, Papers in Houour of J.J. Coulton. BAR International Series 1455, (pp. 13-68).

Hall, J. (2014). A History of the Archaic Greek World, ca. 1200-479 B.C.E., Second Edition. Wiley, Malden and Oxford.

Heikell, R. (1998). Mediterranean Cruising Guide, Fourth Edition. Imray, St. Ives.

Heikell, R. (2001). Greek Waters Pilot, Eighth Edition. Imray, St. Ives.

Horden, P. \& Purcell, N. (2000). The Corrupting Sea: A Study of Mediterranean History. Wiley, Oxford.

Knappett, C. (2011). An Archaeology of Interaction: Network Perspectives on Material Culture and Society. Oxford University Press, Oxford.

Kneuker, T., Dörr, W., Petschick, R., \& Zulauf, G. (2015). 'Upper crustal emplacement and deformation of granitoids inside the uppermost unit of the Cretan nappe stack: constraints from U-Pb zircon dating, microfabrics and paleostress analysis.' International Journal of Earth Science (Geol Rundsch), (pp. 351-67).

Kotsonas, A. (2011). 'Foreign Identity and Ceramic Production in Early Iron Age Crete.' In Rizza (Ed.) Convegno di Studi Identità culturale, etnicità, processi di trasformazione a Creta fra Dark Age e Arcaismo. Università di Catania, Centro di Archeologia Cretese, Catania, (pp. 133-55).

Kotsonas, A. (2012). 'What Makes a Euboean Colony or Trading Station? Zagora in the Cyclades, Methone in the Thermaic Gulf, and Aegean Networks in the $8^{\text {th }}$ Century BC.' In Descoeudres \& Paspalas (Eds.) Zagora in Context, Settlements and Intercommunal Links in the Geometric Period (900-700 BC) Proceedings on the conference held by the Australian Archaeological Institute at Athens and the Archaeological Society at Athens, Athens, 20-22 May 2012. Mediterranean Archaeology. Vol. 25, (pp. 243-57).

Kourayos, Y., Angliker, E., Daifa, K., \& Tully, J. (2018). 'The cult topography of Paros from the $9^{\text {th }}$ to $4^{\text {th }}$ Century BC: A summary.' In Angliker \& Tully (Eds.) Cycladic 
Archaeology and Research, New Approaches and Discoveries. Archaeopress, Oxford, (pp. 135-165).

Kourayos, Y. \& Burns, B. (2017). 'A deposit of small finds from the Sanctuary of Apollo on the island Despotiko.' In Mazarakis Ainian (Ed.) Les Sanctuaries Archä̈ques des Cyclades. Press Universitaires de Rennes, Rennes, (pp. 327-44).

Kourayos, Y., Daifa, K., Ohnesorg, A., \& Papajanni, K. (2012). 'The Sanctuary of Despotiko in the Cyclades, Excavations 2001-2012.' Archäologischer Anzeiger, No. 2, (pp. 93-174).

Kourayos, Y., Sutton, R., \& Daifa, K. (2018). 'Miltiades on Paros: New evidence from Despotiko.' In Angliker \& Tully (Eds.) Cycladic Archaeology and Research, New Approaches and Discoveries. Archaeopress, Oxford, (pp. 113-134).

Kourou, N. (2002). 'Tenos-Xobourgo. From a refuge place to an extensive fortified settlement.' In Stamatopoulou and Yeroulanou (Eds.) Excavating Classical Culture, Recent archaeological discoveries in Greece. Studies in Classical Archaeology I, BAR International series 1031. Oxford, (pp. 255-68).

Kourou, N. (2011). 'From the Dark Ages to the Rise of the Polis in the Cyclades: the case of Tenos.' In Mazarakis Ainian (Ed.) The "Dark Ages" Revisited, Acts of an International Symposium in the Memory of William D.E. Coulson, University of Volos, Volos, 14-17 June 2007, Vol. I. Volos, (pp. 399-414).

Kourou, N. (2015). 'Early Iron Age Mortuary Contexts in the Cyclades. Pots, Function and Symbolism.' In Vlachou (Ed.) Pots, Workshops and Early Iron Age Society; function of the role of ceramics in Early Greece. Etudes d'archeologie 8. CReAPatrimoine, Brussels, (pp. 83-105).

Koutsoumpou, M. (2017). 'Beyond Athens and Corinth. Pottery distribution in the seventh-century Aegean: the case of Kythnos.' In Charalambidou \& Morgan (Eds.) Interpreting the Seventh Century BC, Tradition and Innovation. Archaeopress, Oxford, (pp. 160-72).

Lambrinoudakis, V. (1988). 'Veneration of ancestors in Geometric Naxos.' In Hägg, Marinatos, \& Nordquist (Eds.) Early Greek Cult Practice, Proceedings of the Fifth International Symposium at the Swedish Institute in Athens. Anström, Stockholm, (pp. 235-46).

Lambrinoudakis, V. (2004). 'The Emergence of the city-state of Naxos in the Aegean.' In Lentini, M.C. (Ed.) Le due città di Naxos. Atti del Seminario di Studi Giardini, 
Naxos 29-31 ottobre 2000. Comune di Giardini Naxos, Florence-Milan, (pp. 6174).

Lemos, I. (2002). The Protogeometric Aegean. The Archaeology of the Late Eleventh and Tenth Centuries BC. Oxford University Press, Oxford.

Luke, J. (2003). Ports of Trade, Al Mina and Geometric Greek Pottery in the Levant. BAR International Series 1100, Oxford.

Malkin, I. (2011). A Small Greek World, Networks in the Ancient Mediterranean. Oxford University Press, Oxford.

Manning, J.G. (2018). The Open Sea, The Economic Life of the Ancient Mediterranean World from the Iron Age to the Rise of Rome. Princeton University Press, Princeton and Oxford.

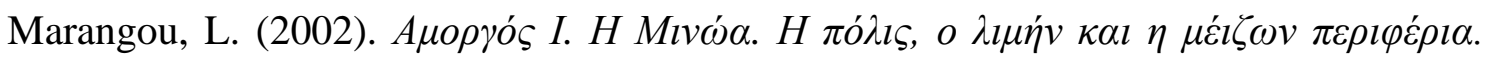

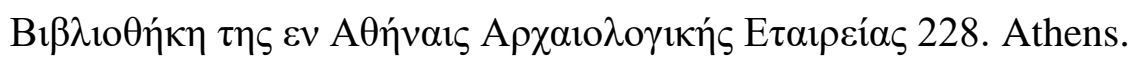

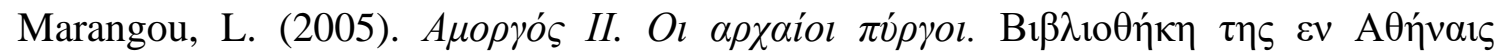

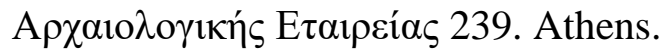

Mazarakis Ainian, A. (1997). From Rulers' Dwellings to Temples, Architecture, Religion and Society in Early Iron Age Greece (1100-700 B.C.). Studies in Mediterranean Archaeology, Vol. CXXI. P. Áström, Jonsered.

Mazarakis Ainian, A. (2005). 'Inside the adyton of a Greek temple, Excavations on Kythnos (Cyclades).' In Yeroulanou \& Stamatopoulou (Eds.) Architecture and Archaeology in the Cyclades, Papers in Houour of J.J. Coulton. BAR International Series 1455, (pp. 87-103).

Mazarakis Ainian, A. (2019) The Sanctuaries of Ancient Kythnos. Presses Universitaires de Rennes, Rennes.

McGilchrist, N. (2010 (17)). McGilchrist's Greek Islands, no. 17, Naxos \& The Lesser Cyclades. Genius Loci, London.

McGilchrist, N. (2010 (18)). McGilchrist's Greek Islands, no. 18, Andros, Tinos, Syros. Genius Loci, London.

McGilchrist, N. (2010 (19)). McGilchrist's Greek Islands, no. 19, Western Cyclades; Kea, Kythnos, Seriphos, Siphnos, Milos, Kimolos. Genius Loci, London.

Mendoni, L. (1994). 'The organisation of the countryside in Kea.' In Structures rurales et sociétés antiques. Actes du colloque de Corfou (14-16 mai 1992) Annales littéraires de l'Université de Besançon, 508. Besançon, (pp. 147-162). 
Meritt, B.D., Wade-Gery, H.T., \& McGregor, M. (1950). The Athenian Tribute Lists, Vol. 3. American School of Classical Studies at Athens, Princeton.

Murray, W. (1987). 'Do Modern Winds Equal Ancient Winds?' Mediterranean Historical Review. Vol. 2, No. 2 (December 1987), (pp. 139-67).

Nixon, L., Moody, J., \& Rackham, O. (1988). 'Archaeological Survey in Sphakia, Crete.' Échos du Monde Classique Vol. 32 (n.s. 7). L’Université, Liège, (pp. 159-74).

Nowicki, K. (2000). Defensible Sites in Crete c. 1200 - 800 B.C. (LM IIIB/IIIC Through Early Geometric). Aegaeum 21, Universite de Liege, Liege and Austin.

Ohnesorg, A. (2017). 'Island-Ionic and Island-Doric architecture on the Cyclades.' In Mazarakis Ainian (Ed.) Les Sanctuaries Archä̈ques des Cyclades. Press Universitaires de Rennes, Rennes, (pp. 55-72).

Palaiokrassa-Kopitsa, L. (2012). 'The Archaeological Evidence form the Agora of Ancient Andros (Cyclades).' In Chankowski \& Karvonis (Eds.) Tout vendre, tout acheter. Structures et équipements des marches antiques. Actes du colloque d' Athènes, 16-19 juin 2009. Ausonis, Bordeaux and Athènes, (pp. 23-35).

Palaiokrassa, L., \& Vivliodetis, E. (2008). 'Recent Evidence on the economy and trading contacts of Andros in Antiquity.' In Papageorgiadou-Banis \& Giannikouri (Eds.) Sailing in the Aegean, readings on the economy and trade-routes, MEAETHMATA 53. De Boccard, Athens, (pp. 139-156).

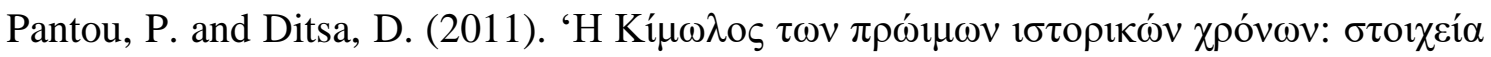

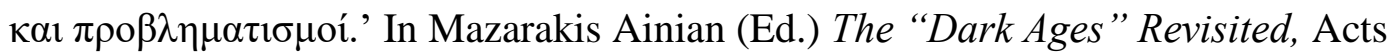
of an International Symposium in the Memory of William D.E. Coulson, University of Volos, Volos, 14-17 June 2007, Vol. I. Volos, (pp. 415-33).

Papadopoulos, J.K. (1997). 'Phantom Euboeans.' Journal of Mediterranean Archaeology. Vol. 10, No. 2, (Dec. 1997), (pp. 191-219).

Papadopoulos, J.K. \& Smithson, E. (2002). 'The Cultural Biography of a Cycladic Geometric Amphora: Islanders in Athens and the Prehistory of Metics.' Hesperia. Vol. 71, No. 2 (April-June). Princeton, (pp. 149-199).

Paspalas, S. (2012). 'Greek Decorated Pottery II: Regions and Workshops.' In Smith \& Plantzos (Eds.) A Companion to Greek Art, Vol. 1. Wiley, Oxford, (pp. 62-104). Pendlebury, J. (1965). The Archaeology of Crete. Norton, New York. Pittinger, J. (1975). 'The Mineral Products of Melos in Antiquity and their Identification.' The Annual of the British School at Athens. Vol. 70, (pp. 191-7). 
Platon, N. (1954). 'Chronique des fouilles et découvertes archéologiques en Grèce en 1953.' Bulletin de correspondence hellénique. Vol. 78. (pp. 95-224).

Pugsley, P. (2010). Blue Guide Crete. Norton, London.

Renfrew, C. (1982). 'Bronze Age Melos.' In Renfrew \& Wagstaff (Eds.) An Island Polity, the archaeology of exploitation in Melos. Cambridge University Press, Cambridge, (pp. 264-290).

Rubensohn, O. (1962). Das Delion Von Paros. F. Steiner, Wiesbaden.

Schilardi, D. \& Katsonopoulou, D. (Eds.) 2010. Paria Lithos, Parian Quarries, Marble and Workshops of Sculpture. The Paros and Cyclades Institute of Archaeology, Archaeological and Historical Studies, 1. Athens.

Seidel, M. (2003). Techno-sedimentary evolution of middle Miocene supra-detachment basins (Western Crete, Greece). Inaugural-Dissertation, University of Köln.

Sfyroera, A. (2018). 'Naxos, the largest Cycladic island with a single polis: A survey through ancient times.' In Angliker \& Tully (Eds.) Cycladic Archaeology and Research, New Approaches and Discoveries. Archaeopress, Oxford, (pp. 325-38).

Shaw, J. (1982). 'Excavations at Kommos (Crete) during 1981.' Hesperia. Vol. 51, No. 2 (Apr.-Jun. 1982), (pp. 164-195).

Shaw, J. \& Shaw, M. (Eds.) (2000). Kommos IV, The Greek Sanctuary, Part 1. Princeton University Press, Princeton.

Sheedy, K. (2005). 'Three Vase Group from the Purification Trench on Rhenia and the Evidence for a Parian Pottery Tradition.' The Annual of the British School at Athens. Vol. 80, (pp. 151-90).

Sheedy, K. (2006). The Archaic and Early Classical Coinages of the Cyclades. Royal Numismatic Society Special Publication No. 40. London.

Shelford, P. (1982). 'The geology of Melos.' In Renfrew \& Wagstaff (Eds.) An Island Polity, the archaeology of exploitation in Melos. Cambridge University Press, Cambridge, (pp. 74-81).

Simantoni-Bournia, E. (2002). 'The early phases of the Hyria Sanctuary on Naxos. An overview of the pottery.' In Stamatopoulou \& Yeroulanou (Eds.) Excavating Classical Culture, Recent archaeological discoveries in Greece. Studies in Classical Archaeology I. BAR International series 1031. Oxford, (pp. 269-80).

Stampolidis, N. (1990). 'Eleutherna on Crete: An Interim Report on the GeometricArchaic Cemetery.' The Annual of the British School at Athens, Vol. 85. (pp. 375403). 
Strassler, T., Panagopoulou, E., Runnels, C., Murray, P., Thompson, N., Karkanas, P., McCoy, F., \& Wegmann, K. (2010). 'Stone Age Seafaring in the Mediterranean: Evidence from the Plakias Region for the Lower Palaeolithic and Mesolithic Habitation of Crete.' Hesperia. Vol. 79, No. 2 (April-June 2010), (pp. 145-90).

Stefanakis, M. (1999). 'The Introduction of Coinage in Crete and the Beginning of Local Mining.' In Chaniotis (Ed.) From Minoan Farmers to Roman Traders: Sidelights of the Economy of Ancient Crete. F. Steiner, Stuttgart, (pp. 247-68).

Sutton, R. (1991). 'Ceramic Evidence for Settlement and Land Use in the Geometric to Hellenistic Periods.' In Cherry, Davis, \& Mantzourani. Landscape Archaeology as Long-Term History, Northern Keos in the Cycladic Islands, From Earliest Settlement until Modern Times. Monumenta Archaeologica, Vol. 16. Institute of Archaeology, U.C.L.A. Los Angeles, (pp. 245-63).

Sweetman, R. (2013). The Mosaics of Roman Crete, Art, Archaeology and Social Change. Cambridge University Press, Cambridge, New York.

Sweetman R. (2016). 'Networks: Exile and Tourism in the Roman Cyclades.' In Alcock, Egri, \& Frakes (Eds.) Beyond Boundaries: Connecting visual cultures in the provinces of Ancient Rome. Getty Publications, Los Angeles, (pp. 46-61).

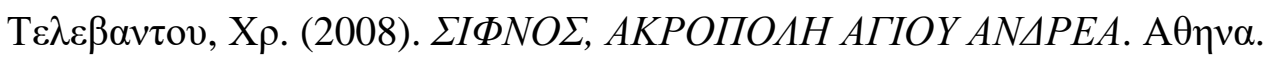

Televantou, Ch. (2017). 'The Acropolis of Aghios Andreas, Siphnos. The Sanctuary $\left(8^{\text {th }}\right.$ $2^{\text {nd }}$ Century BC).' In Mazarakis Ainian (Ed.) Les Sanctuaries Archä̈ques des Cyclades. Rennes. (pp. 367-78).

Thomatos, M. (2006). The Final Revival of the Aegean Bronze Age. A case study of the Argolid, Corinthia, Attica, Euboea, the Cyclades and the Dodecanese during LH IIIC Middle. BAR International Series 1498. Oxford.

Tzachili, I. (2005). 'Excavation on Thera and Therassia in the $19^{\text {th }}$ Century: A Chronicle.' Journal of Mediterranean Archaeology. Vol. 18, No. 2., (pp. 231-57).

Vacek, A. (2017). 'Al Mina and changing patterns of trade: the evidence from the eastern Mediterranean.' In Charalambidou \& Morgan (Eds.) Interpreting the Seventh Century BC, Tradition and Innovation. Archaeopress, Oxford, (pp. 47-59).

Vagnetti, L. (1989). 'A Sardinian Askos from Crete.' The Annual of the British School at Athens. Vol. 84, (pp. 355-60).

Van Wees, H. (2013). 'The Economy.' In Raaflaub and Van Wees (Eds.) A Companion to Archaic Greece. Oxford, (pp. 444-67). 
Viviers, D. (2009). 'Recherches Archéologiques à Itanos (Crète Orientale). Revue Archéologique (2009). Paris, (pp. 208-219).

Viviers, D. \& Tsingarida, A., (2014). 'Facing the Sea: Cretan Identity in a Harbour-city Context.' In Gaignerot-Driessen \& Driessen (Eds.) Cretan Cities: Formation and Transformation. Aegis 7. Presses Universitaires de Louvain, Louvain, (pp. 165-82).

Vlachopoulos, A. (2008a). 'The Late Helladic IIIC 'Grotta Phase' of Naxos. Its synchronisms in the Aegean and its non-synchronisms in the Cyclades.' In DegerJalkotzy \& Zavadil (Eds.) LH IIIC Chronology and Synchronisms; Proceedings of the International Workshop held at the Austrian Academy of Sciences at Vienna, May $7^{\text {th }}$ and $8^{\text {th }}$, 2001. Verlag der Österreichischen Akademier der Wissenschaften, Wien, (pp. 217-34).

Vlachopoulos, A. (2008b). 'A Late Mycenaean Journey from Thera to Naxos: The Cyclades in the Twelfth Century BC.' In Brodie, Doole, Cavalas, \& Renfrew (Eds.)

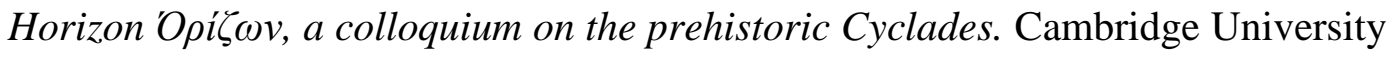
Press, Cambridge, (pp. 479-91).

Wallace, S. (2010). Ancient Crete. From Successful Collapse to Democracy's Alternatives, Twelfth to Fifth Centuries B.C.. Cambridge University Press, Cambridge.

Watrous, V. (1998). 'Crete and Egypt in the Seventh Century B.C., Temple A at Prinias.' In Cavanagh, Curtis, Coldstream, \& Johnson (Eds.) Post-Minoan Crete, Proceedings of the First Colloquium. British School at Athens Studies 2. London, (pp. 75-9).

Whitley, J. (2013). 'Crete.' In Raaflaub \& Van Wees (Eds.) A Companion to Archaic Greece. Wiley-Blackwell, Oxford, (pp. 273-93).

Whitley, J. (2015). 'Agency, Personhood and the Belly-Handled Amphora: Exchange and Society in the Ninth Century Aegean.' In Vlachou (Ed.) Pots, Workshops and Early Iron Age Society; function of the role of ceramics in Early Greece. Etudes d'archeologie 8. CReA-Patrimoine, Brussels, (pp. 107-26).

Wilson, D. (2008). 'Early Prepalatial Crete.' In Shelmerdine (Ed.), The Cambridge Companion to the Aegean Bronze Age. Cambridge University Press, Cambridge, (pp. 77-104).

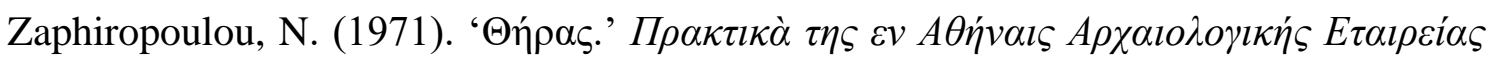
(ПAE). Athens, (pp. 226-230). 
Mare Nostrum, ano 2021, v. 12, n. 2

\section{As Cíclades E Creta Na Idade Do Ferro: Diferentes Abordagens À Conectividade EsPeculativamente Relacionadas CoM A SeguranÇA Alimentar}

Doug Forsyth

\section{RESUMO}

Este artigo oferece um estudo de caso de algumas das ilhas do arquipélago das Cíclades examinando a conectividade e a insularidade entre 1000 e 500 a.C. Nas Cíclades, evidências da interação com áreas fora e dentro do arquipélago são observáveis em muitas das ilhas. Argumentar-se-á que os fatores ambientais, predominantemente de baixa pluviosidade, podem ser pelo menos parte da explicação para a adoção de uma estratégia de deslocamento para além da costa de uma ilha nessa região. Os ilhéus cicládicos procuraram desenvolver fortes redes de afiliação com parceiros comerciais de outras regiões, talvez para servir como apoios durante períodos de baixa produtividade alimentar. Em comparação com o material cicládico, a evidência arqueológica de itens cretenses, encontrados fora de Creta, não é tão consistente. Este artigo sugere de forma especulativa que os cretenses, vivendo em um ambiente mais fértil, não sentiram a mesma necessidade dos ilhéus cicládicos de estabelecer redes de afiliação para fins de segurança alimentar.

\section{PALAVRAS-CHAVE}

Cíclades, Creta, Conectividade, Pluviosidade, Segurança Alimentar. 